\title{
Changes in Ecosystem Carbon Following Afforestation of Native Sand Prairie
}

\section{N. J. Mellor}

Natural Resource Ecology Lab.

Colorado State Univ.

Ft. Collins, CO 80523

J. Hellerich

R. Drijber

Univ. of Nebraska

Lincoln, NE 68508;

\section{S. J. Morris*}

Biology Dep.

Bradley Univ.

1501 W. Bradley Ave.

Peoria, IL 61625

M. E. Stromberger

Soil and Crop Sciences

Colorado State Univ.

Ft. Collins, CO 80523

E. A. Paul

Natural Resource Ecology Lab.

Colorado State Univ.

Ft. Collins, CO 80523
Determining the dynamics of carbon $(C)$ as a function of vegetation and residue inputs is important for predicting changes in ecosystem functions and the global C cycle. Litter and soil samples were analyzed from plantations of eastern red cedar (Juniperous virginiana) and ponderosa pine (Pinus ponderosa) and native prairie at the Nebraska National Forest to evaluate the impact of different types of land management on soil $\mathrm{C}$ contents and turnover rates. Total soil $\mathrm{C}$ to a depth of $1 \mathrm{~m}$ was greatest in the cedar stands. Pine ecosystems stored more $\mathrm{C}$ in the tree biomass and litter but lost more native prairie $\mathrm{C}$ from the soil. The soil ${ }^{13} \mathrm{C}$ content showed $82 \%$ of the original, and prairie $C$ remained under cedars compared with $\sim 45 \%$ under pine. Soil cation contents were greatest overall in cedar soils and lowest in pine. The $\mathrm{C}$ content in cedar soils was strongly related to Ca content. Differences in microbial community fatty acid profiles were related to vegetation type, and nutrients explained $\sim 60 \%$ of the variation in profiles. Our research indicates that changes in soil $\mathrm{C}$ and nutrient content following conversion from prairie to forest are dependent on tree species planted, characteristics of the plant litter, and cation cycling in the plant-soil system.

Abbreviations: EL, ester-linked; FAME, fatty acid methyl ester; MRT, Mean residence time; PCA, principal components analysis; SOC, soil organic carbon.

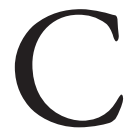

oncern over the impacts of anthropogenic disturbance on the global C cycle has focused attention on soil organic C (SOC) dynamics. Disturbances such as land use change, acid deposition, and alterations to climate patterns impact SOC content, turnover rates, and controls on SOC dynamics. Soil C pool dynamics, currently used for modeling of global climate change scenarios, invoke the known controls on SOC dynamics to infer $\mathrm{C}$ pools and flux rates. However, studies suggest that controls are not adequately understood across the ever changing set of land use change scenarios (Pacala et al., 2001; Schmidt et al., 2011; Smith et al., 2012).

Many studies over the last $20 \mathrm{yr}$ have focused specifically on alterations to SOC content and dynamics as a consequence of land use change. Large areas of agriculture, pasture land, and native landscapes, such as prairie, have been converted to forested landscape either as a consequence of intentional management decisions (plantation, shelterbelt) or through invasion of native or nonnative species (encroachment). Afforestation currently affects large areas of temperate ecosystems as a result of regrowth of forest on former agricultural lands and tree invasion of prairies. Post and Kwon's (2000) review of global afforestation research found that soil C accumulation rates ranged from -0.141 to $0.617 \mathrm{Mg} \mathrm{C} \mathrm{ha}^{-1} \mathrm{yr}^{-1}$, with large differences occurring in a few sites. Returning land from agriculture to forest generally increases ecosystem $\mathrm{C}$ stocks by $2.4 \mathrm{Mg} \mathrm{C} \mathrm{ha}^{-1} \mathrm{yr}^{-1}$ with coniferous trees showing the greatest variability in C accrual (Guo and Gifford, 2002; Paul

\footnotetext{
Soil Sci. Soc. Am. J. 77:1613-1624

doi:10.2136/sssaj2012.0327

Received 28 Sept. 2012

*Corresponding author (sjmorris@bradley.edu).

(C) Soil Science Society of America, 5585 Guilford Rd., Madison WI 53711 USA

All rights reserved. No part of this periodical may be reproduced or transmitted in any form or by

any means, electronic or mechanical, including photocopying, recording, or any information storage and retrieval system, without permission in writing from the publisher. Permission for printing and for reprinting the material contained herein has been obtained by the publisher.
} 
et al., 2003; Morris et al., 2007, 2010). Studies, such as those of Johnson (1992), Ellert and Gregorich (1996), and Hooker and Compton (2003), found increases in aboveground litter and soil $\mathrm{C}$ in deeper soil horizons but not in the shallow layers of pine soils, which can show significant SOC loss (Pregitzer and Palik, 1997). Sandy soils tended to lose $C$ under pine stands, with the exception of those with higher Ca levels (Paul et al., 2003). These studies have failed to provide general understandings or principles by which we understand the impacts of land use change on SOC. This suggests that our current knowledge of the effects of afforestation on SOC is not adequate (Johnson, 1992; Post and Kwon, 2000; Berthrong et al., 2009; Morris et al., 2010).

In this study, we examined factors that affect SOC pools in afforested eastern red cedar and ponderosa pine plantations established on native sand prairie at the Nebraska National Forest at Halsey, NE. The plantations were established as described by Pool (1953) in the early 1900 s on $\mathrm{C}_{3}-\mathrm{C}_{4}$ grasslands; therefore, the SOC contains a ${ }^{13} \mathrm{C}$ signature that allows changes in prairie $\mathrm{C}$ to be differentiated from $\mathrm{C}$ contributed by the tree plantation species. Previous studies suggest that afforestation of prairie has significant consequences for C pools. Studies of woody encroachment of native grasslands provide evidence that changes in ecosystem and soil $\mathrm{C}$ occur as a result of tree invasion in these systems (Harrison et al., 1995; Houghton et al., 1999; Jackson et al., 2000; Norris et al., 2001a, 2001b). In one study of eastern red cedar invasion into $\mathrm{C}_{4}$ grassland, the $\delta^{13} \mathrm{C}$ content suggested a $42 \%$ turnover of $\mathrm{C}_{4}$ to $\mathrm{C}_{3}$ SOC in the 0 - to 2.5 - $\mathrm{cm}$ layer and $6 \%$ at lower depths (Smith and Johnson, 2003). However, the total $\mathrm{C}$ content did not significantly change at any depth. Pacala et al. (2001) found that more than $1 \mathrm{Mg} \mathrm{C} \mathrm{ha}^{-1} \mathrm{yr}^{-1}$ accumulated in areas of woody encroachment such as juniper woodlands. The difference between these findings could be due to the increase in soil C stocks in areas with low precipitation and a decrease in areas with high precipitation in areas with woody encroachment (Jackson et al., 2002).

Controls on SOC dynamics are difficult to study as they include climate, time, vegetation, topography, and parent materials. Studies, such as ours, that involve a single soil type sampled at a single slope position with the same aspect, hold many of these interactive controls constant allowing the impacts of vegetation on SOC dynamics to be more easily evaluated. In terms of modeling, texture, which would be included as a component of parent material in the above list, is considered an important control on SOC content and turnover (Eusterhues et al., 2003). There is ample evidence that silt and clay content acting as part of the "matrix stabilization" contribute to long-term storage of SOC through protection in soils (Baldock and Skjemstad, 2000; Kögel-Knabner et al., 2008). The soil present on the site chosen for this study has 95 to $98 \%$ sand content. The high sand content of the prairie soil on this site will minimize the effects of texture on SOC level and composition. The Century model uses soil clay, and at times sand and silt content, as a surrogate for the sum of mineral-organic interactions. When this was combined with abiotic factors, litter and SOC quality the model output had an $r^{2}$ of 0.93 between simulated and observed SOC levels for the Grassland Biome worldwide (Parton et al., 1993). In humid regions with soils that are low in exchangeable $\mathrm{Ca}$, the SOC content can be related to iron and aluminum concentrations of weathered products that form metastable intermediates (Masiello et al., 2004). The presence of a large amount of oxide specific surface area and absorption to micropores is assumed to be responsible for their ability to stabilize SOC (Eusterhues et al., 2005). This mechanism of stabilization is considered dominant in acidic, sandy forested soils (Kaiser et al., 2002) but Masiello et al. (2004) also argued that this process can also apply in humid grasslands where weathering has occurred. It is of greater significance at depth than in surface horizons (Eusterhues et al., 2007). Clay-Ca-sesquioxide interactions are also of importance in SOC stabilization but these have yet to be accurately determined (Kay and Angers, 2000). Accumulation of SOC in sandy soils has been found to be greater on the surface as a consequence of litter inputs (Zinn et al., 2007) suggesting that depth by mineral by tissue input interactions may be an important consideration when evaluating mechanisms of SOC retention in soils.

The extremely low clay content on the study site will minimize textural and mineral controls on SOC storage allowing changes to the SOC as a consequence of specific vegetation types to be identified. Vegetation has been a well-recognized controller of soil formation since the understanding of soils as a science was initially developed by scientists such as Müller and Dokuchaev (Feller and Bernoux, 2008). In this study, evaluating plantation stands of different tree types with known history in the same climate on a native grassland with a ${ }^{13} \mathrm{C}$ signal reduces confounding factors and allows the differences in the impacts of tree type on soils to be detected. Morris et al. $(2007,2010)$ found significant effects of tree type (deciduous versus conifer) on SOC retention. The amount of $\mathrm{C}$ stored under each tree type on the same soil type differed and those differences were interactively related to Ca content and texture. The mechanisms by which soil chemistry interacts with vegetation type to alter SOC retention requires further study.

The goals of our study were to examine SOC content in prairie, pine, and cedar stands at the Nebraska Forest in a manner that would provide data on current content and $\mathrm{C}$ accrual following land use change, and provide some understanding of how soil and plant chemistry and litter microbiology influence that change. We hypothesized that $\mathrm{C}$ content under cedar and pine would differ from that of the native prairies and that the impacts on SOC would differ for each species planted. We expected that differences in specific characteristics of the trees such as the quantity and quality of litter and root derived substrates and/or symbionts would have consequences for $\mathrm{C}$ accrual rates on this site. Studies to date have suggested that the effects of land use change on SOC pools cannot yet be generalized in a manner that will produce a set of specific controls by which to parameterize models. To address these limitations, our study also examined some of the controls on SOC accrual in soils. The second hypothesis evaluated in this study was that the importance of spe- 
cific soil chemistry controls and soil microbiota for SOC accrual would differ between the species studied. We predicted that increased levels of $\mathrm{Ca}$ and associated changes in litter microbiota would result in greater prairie $\mathrm{C}$ retention and SOC contents in the cedar soils than the pine, especially at depth. To address this hypothesis we collected additional data on microbial community composition, soil nutrients, and vegetation chemistry. Improved knowledge of the effects of specific vegetation changes on SOC pools should allow a more realistic set of controls to be used in modeling efforts.

\section{MATERIALS AND METHODS \\ Site Description and Sampling}

The sites selected for study were located at the Nebraska National Forest at Halsey, NE ( $\left.41^{\circ} 52^{\prime} \mathrm{N} ; 100^{\circ} 20^{\prime} \mathrm{W}\right)$. Pool (1953) provides documentation of the development of the site including information on research goals and a history of initial plantings. The 90,444 acre forest is composed of stands of a variety of species including ponderosa pine and eastern red cedar interspersed with areas of sand prairie providing large replicated stands across the expanse of the research area. The area is currently managed by the Bureau of Land Management as grazing land for cattle. The soil series sampled was Valentine and the soil contained between 95 and $98 \%$ sand.

Soil samples were collected from three pine plantations ( $72 \mathrm{yr})$, three older cedar plantations $(55 \mathrm{yr})$, three younger cedar plantations $(25 \mathrm{yr})$, three areas planted with alternating rows of pine and cedar, and three prairie areas that were treated as replicates. In each area, six samples were collected to a depth of $30 \mathrm{~cm}$. These cores were divided to reflect three depths of 0 to 5,5 to 15 , and 15 to $30 \mathrm{~cm}$. Each of those six samples, representing an independent field replicate for that area, consisted of six composited cores collected from not more than $1 \mathrm{~m}^{2}$ in area. One soil sample of two composited cores was also taken from 30 to 50 and 50 to $100 \mathrm{~cm}$ for each area. All samples were taken at midslope from a moderate, north facing sloping site ( $20 \%$ slope). All samples were returned to the lab and refrigerated at $4{ }^{\circ} \mathrm{C}$.

Soils were sieved to $2 \mathrm{~mm}$ and visible plant material was removed. Soil moisture content was determined on a subsample of known weight by drying at $105^{\circ} \mathrm{C}$. Dry soil weight (corrected for moisture) was then divided by the area sampled (soil core volume) to determine bulk density. Six litter samples were taken in each plantation by removing litter on the soil surface using a $15-\mathrm{cm}$ diameter litter sampler. Litter was oven dried at $60^{\circ} \mathrm{C}$ and then weighed. Soils from the pine, older cedar, and prairie sites were evaluated using the complete suite of analyses described below; the stands with pine/cedar mixed and young cedar trees were only evaluated for soil and litter $\mathrm{C}$ and $\mathrm{N}$ content, ${ }^{13} \mathrm{C}$, and bulk density.

\section{Carbon, Nitrogen, Carbon-13, and Nutrient Content}

Samples were ground using a roller mill with soil ground against steel bars in sealed jars to pass a $180-\mu \mathrm{m}$ sieve (Harris and
Paul, 1989). Soil was analyzed for organic $C$ and total $N$ using combustion analysis with a Carlo Erba NA 1500 CN Analyzer (Carlo Erba, Milan, Italy). Samples were tested with $\mathrm{HCl}$ and examined for gas loss. The samples failed to react with $\mathrm{HCl}$ suggesting that inorganic $\mathrm{C}$ was not present in these soils, so values are presented here as organic C (Paul et al., 2001). Carbon content of litter samples was determined using a Leco Truspec $\mathrm{CN}$ analyzer (St. Joseph, MI) and scaled to $\mathrm{Mg} \mathrm{ha}^{-1}$ using bulk density calculated for each sample. Isotopic analysis was measured using a Carlo Erba NA 1500 CN Analyzer coupled to a GV Isochrom mass spectrometer (GV Instruments, Manchester, UK) (Harris and Paul, 1989). The percentage of prairie $\mathrm{C}$ remaining in pine and cedar stand soils was calculated using the $\delta^{13} \mathrm{C}$ value of the prairie soils sampled at each depth, the $\delta^{13} \mathrm{C}$ of pine and cedar input litter $(-26.6)$, and $\delta^{13} \mathrm{C}$ of pine and cedar soil $\left(\mathrm{C}_{\text {current }}\right)$ for each stand of interest (O'Leary, 1981) as in Eq. [1].

$$
\% \text { Prairie } \mathrm{C}_{\text {remaining }}=1-\frac{\left(\delta^{13} \mathrm{C}_{\text {current }}-\delta^{13} \mathrm{C}_{\text {prairie }}\right)}{\left(\delta^{13} \mathrm{C}_{\text {tree litter }}-\delta^{13} \mathrm{C}_{\text {prairie }}\right)}
$$

Mean residence times (MRTs) of prairie $\mathrm{C}$ in the cedar and pine soils were calculated as in Eq. [2] assuming first order kinetics (Paul and Clark, 1996) based on the amount of prairie $\mathrm{C}$ remaining in the various sites at the time of sampling $\left(\mathrm{SOC}_{\text {sampling }}\right)$ relative to that in the prairie at this site which estimates the $\mathrm{C}$ present at the time of planting $\left(\mathrm{SOC}_{\text {planting }}\right)$ using Eq. [2] and reported as MRT (years) $=1 / k$.

$$
\mathrm{SOC}_{\text {sampling }}=\mathrm{SOC}_{\text {planting }} \mathrm{e}^{-k t}
$$

Assumptions involved in this calculation were that (i) the $S O C$ and ${ }^{13} \mathrm{C}$ content of the native prairie were the same at the time of our sampling as when the prairie was converted to trees; (ii) the decomposition rate of native prairie SOC under trees followed first order kinetics; (iii) the suggested differences in decomposition of $\mathrm{C}_{3}$ and $\mathrm{C}_{4}$ derived grasses (Wynn and Bird, 2007) and the ${ }^{13} \mathrm{C}$ fractionation at the root, microorganism, SOC decomposition, and mineral matrix interactions (Werth and Kuzyakov, 2010) are not so great that the soil ${ }^{13} \mathrm{C}$ signal does not represent that of the input plant materials (Boutton, 1996); and (iv) the differences in tracer exposure times that affect MRT calculations (Paul et al., 2006) in the pine and cedar soils did not invalidate our conclusions based on a comparative analysis on a single soil type. These assumptions are further addressed in the discussion section. The measured ${ }^{13} \mathrm{C}$ signal of both the cedar and pine litter $(-26.6 \%$.) was used for the calculation of tree inputs at all soil depths.

Soil cations, Bray $\mathrm{P}$, and $\mathrm{pH}$ were analyzed at the Michigan State University Soil and Plant Nutrient Laboratory using standard methods (Brown, 1998). The plant tissue cation and P content were determined at the A and L Great Lakes Laboratories Incorporated (Fort Wayne, IN). Litter, cation, and P con- 
tent were determined at the Soil Testing Lab located at Colorado State University using a plant digestion in nitric and perchloric acid. Soil characteristics are presented per sampled horizon depth based on bulk density and sample depth. For the purposes of evaluating differences in ecosystem contents as a consequence of land use change specifically, soil characteristics are also presented on a total profile basis using bulk density and profile depth as corrected for equivalent weights. The differences in soil weight that are inherent as a consequence of the impacts of land use and vegetation on soils require adjustments in soil weight so that differences in content are not an artifact of differences in total soil profile weight magnified through differences in bulked density summed over several depths. Corrections for equivalent weight were made in a manner consistent with other studies (Ellert and Gregorich, 1996; Paul et al., 2001; Six et al., 2002) by summing the total profile weight for all soils and correcting to the weight of the preexisting condition which in this case was the prairie. Profile soil weights were corrected by adjusting the depth of the 50 to $100 \mathrm{~cm}$ depth so that the total profile is equivalent to that of the prairie profile weight.

\section{Tree Biomass}

The diameter at breast height of trees was measured and used to determine total aboveground biomass $\mathrm{C}$ using the allometric equations of Means et al. (1994) for the ponderosa pines and Schnell (1976) for the eastern red cedar. Biomass values were scaled to forest area using conversion factors from Birdsey (1992).

\section{Fatty Acid Methyl Ester Extraction Analysis}

Fatty acid methyl ester (FAME) extractions were conducted at the University of Nebraska on litter samples collected using sterile technique and immediate refrigeration using the methods of Grigera et al. (2007) for ester-linked (EL) FAME extraction. This method (EL-FAME) uses a mild alkanolysis procedure to hydrolyze EL fatty acids directly from their parent compound (e.g., neutral, glycol-, and phospholipids) within microbial cells without prior removal of the cells from the soil. Recovery of fatty acids from microbial cells is higher with this procedure compared with other methods since it includes more than just phospholipids and avoids extraction efficiency issues with removal of intact phospholipids from microbial cells within the soil. This method also gives a more complete picture of fungal fatty acids, particularly those from arbuscular mycorrhizal fungi (Olsson, 1999; Grigera et al., 2007). Fatty acid methyl esters were assayed by gas chromatography using an internal standard, methyl-nonadec-

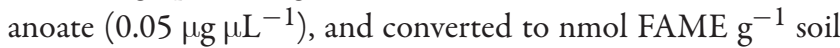
(Grigera et al., 2006). Individual FAMEs were related to microbial populations using biomarkers previously determined by Vestal and White (1989), Olsson et al. (1995), Zak et al. (1996), Bossio and Scow (1998), Bååth (2003), and Högberg et al. (2007) (see Table 8). Fatty acids are differentiated by the number of $\mathrm{C}$ atoms, counted from the omega end of the fatty acid chain, and the number of double bonds. The prefixes $i$, a, and cy denote iso, anteiso, and cyclic, respectively. The numbers in parentheses are the carbon atoms where two double bonds or a cyclic ring exists.

\section{Data Analysis}

Univariate data were evaluated to confirm they met the assumptions of ANOVA. Log and inverse transformations were necessary for a number of variables to meet the assumptions of normality. Differences among sampled variables were evaluated using ANOVA (Proc GLM) (SAS, 1995). All differences reported were significant at $p<0.05$.

The relationships of soil cations, Bray $\mathrm{P}$, and $\mathrm{pH}$ to $\mathrm{C}$ and $\mathrm{N}$ content were evaluated using Amos 4.0 (Small Waters Corporation, Chicago, IL), a system for structural modeling and causal analysis often referred to as path analysis (Arbuckle and Wothke, 1999). Traditional multiple regression models require many degrees of freedom as a result of the diverse array of interaction terms that occur with multiple, covarying environmental variables. Even if power is available in a multiple regression model, the use of a large number of interaction terms often produces complex models that are not consistent with real-world scenarios (Arbuckle and Wothke, 1999). Because of the path construction, exploratory path analysis does not require large sample sizes or number of interaction terms. The path model was built using combinations of variables that significantly covaried with either the dependent variable or each other. Exploratory path analysis allows variables to be arrayed in hierarchical arrangements that allow for quantification of direct and indirect effects of environmental variables.

Litter FAMEs were analyzed by principal components analysis (PCA) after normalizing the data as relative mol \%, using the PC-ORD statistical package (version 6, MjM Software, Gleneden Beach, OR). Soil $\mathrm{pH}$ and nutrients (C, N, Ca, P, K, and Mg) were correlated with principal components in PC-ORD to identify associations between soil variables and litter FAME profiles.

\section{RESULTS}

\section{Soil Organic Matter Dynamics}

Soil bulk density was generally greatest under pine (Table 1). In the 0 to $5 \mathrm{~cm}$ layer, old cedar stands had greater SOC (6.43 $\mathrm{Mg} \mathrm{ha}^{-1}$ ) relative to pine $\left(4.06 \mathrm{Mg} \mathrm{ha}^{-1}\right)$, while pine did not differ from prairie $\left(3.67 \mathrm{Mg} \mathrm{ha}^{-1}\right)$. Old cedars had $0.65 \mathrm{Mg} \mathrm{N} \mathrm{ha}^{-1}$, whereas pine had the lowest soil $\mathrm{N}$ at $0.34 \mathrm{Mg} \mathrm{N} \mathrm{ha}^{-1}$. The other land use types were intermediate (Table 1). The deeper soil layers did not differ from each other in soil $\mathrm{C}$ or $\mathrm{N}$ content except under pine stands, where deeper soils had lower $\mathrm{C}$ and $\mathrm{N}$ content.

Changes in SOC content from residue incorporation and prairie $\mathrm{C}$ loss, resulting from vegetation change, could be estimated using the native prairie $\delta^{13} \mathrm{C}$ as the $\delta^{13} \mathrm{C}$ at time of planting. The upper layer of cedar $(-23.31 \%)$ and pine $(-23.74 \%$ o soil did not differ significantly, although both were significantly more negative than the prairie $\delta^{13} \mathrm{C}$ value of $-19.63 \%$ (Table 1). The ${ }^{13} \mathrm{C}$ values of cedar $\mathrm{C}$ relative to prairie $\mathrm{C}$ indicated that $82 \%$ of the original prairie $\mathrm{C}$ remained in the cedar soil at the time 
of sampling. As the cedar soil contained a total of $6.43 \mathrm{MgC} \mathrm{ha}{ }^{-1}$ compared with the $3.67 \mathrm{Mg} \mathrm{C} \mathrm{ha}^{-1}$ currently under the prairie, it was estimated that older cedars had accumulated $3.42 \mathrm{Mg} \mathrm{ha}^{-1}$ of cedar $\mathrm{C}$ in addition to retaining $3.01 \mathrm{Mg} \mathrm{C} \mathrm{ha}{ }^{-1}$ prairie $\mathrm{C}$ in the top $5 \mathrm{~cm}$ since planting. The pines added $2.41 \mathrm{Mg} \mathrm{ha}^{-1}$ but retained only $45 \%$ of the original prairie C. Given these values, the MRT of prairie C was estimated to be $278 \mathrm{yr}$ in the old cedar stands versus $90 \mathrm{yr}$ in the pine (Table 1). Similar values occurred for the cedar soils at depth but the pine soils lost even more of the original prairie $\mathrm{C}$ resulting in shorter MRTs for the original prairie $\mathrm{C}$ in the deeper soils.

Soil C contents, to an equivalent weight of $1 \mathrm{~m}$ based on the cumulative mass of the prairie soil, differed among sites. The old cedar soil contained the most C with $37.0 \mathrm{Mg} \mathrm{ha}^{-1}$ (Table 2). The young cedar, mixed stand, and prairie soils were lower than the old cedar soils and did not differ from each other. The pine soil profile contained the least $\mathrm{C}$ with $25.1 \mathrm{Mg} \mathrm{ha}^{-1}$ (Table 2). The cedar stands contained $51.4 \mathrm{Mg} \mathrm{C} \mathrm{ha}^{-1}$ in above ground biomass, $9.85 \mathrm{Mg} \mathrm{C} \mathrm{ha}^{-1}$ in litter, and $37.0 \mathrm{Mg} \mathrm{Cha}^{-1}$ in the soil for an ecosystem C content of $98.2 \mathrm{Mg} \mathrm{Cha}^{-1}$. Given an ecosystem C content of $36.7 \mathrm{Mg} \mathrm{ha}^{-1}$ for the prairie system, there was an increase in ecosystem C content of $61.5 \mathrm{Mg} \mathrm{Cha}^{-1}$ on the old cedar sites. The older cedars were planted on this site $55 \mathrm{yr}$ before sampling resulting in an accrual rate of $1.12 \mathrm{MgC} \mathrm{ha}^{-1} \mathrm{yr}^{-1}$. The pine ecosystem storage was slightly greater than cedar at $1.39 \mathrm{Mg} \mathrm{C} \mathrm{ha}{ }^{-1}$ annual accrual (Table 2).

Soil $\mathrm{N}$ across the profile showed a slightly different pattern than observed for $\mathrm{C}$. The prairie and cedar soils had greater total profile $\mathrm{N}$ than the pines; however, the soil $\mathrm{C}$ to $\mathrm{N}$ ratio did not differ between cedar and the pine soils (Table 3). Overall, litter $\mathrm{C}$ and $\mathrm{N}$ content were greatest in the pine stands and lowest in the prairie (Tables 2 and 3). On the basis of $\mathrm{C}$ to $\mathrm{N}$ ratio estimates of 126:1 for cedar (Norris et al., 2001b) and 265:1 for pine (Kaye et al., 2005) biomass, cedar sites had more biomass $\mathrm{N}$ than the pine. The prairie biomass had little $\mathrm{N}$ compared with pine or cedar. On the basis of the different stand ages as for $\mathrm{C}$ above, the cedar site accrued $\mathrm{N}$ at a rate of $11 \mathrm{~kg} \mathrm{Nha}^{-1} \mathrm{yr}^{-1}$ while the pine site lost $10 \mathrm{~kg} \mathrm{~N} \mathrm{ha}^{-1} \mathrm{yr}^{-1}$.

\section{Soil and Litter Chemical Characteristics}

The old cedar soils had a greater $\mathrm{pH}$ in the upper two soil layers and a lower $\mathrm{pH}$ at depth compared with prairie soils ( $\mathrm{Ta}$ ble 4). The differences between old cedar and prairie soils are also observed in the young cedar and mixed soils; however, the
Table 1. Bulk density, $\mathrm{C}$ and $\mathrm{N}$ content, $\delta^{13} \mathrm{C}$, percent original remaining prairie $\mathrm{C}$ calcedar, mixed (cedar and pine), pines, and from prairie soils at the Nebraska National Forest, NE, for each depth of 0 to 5,5 to 15 , and 15 to $30 \mathrm{~cm}$. +

\begin{tabular}{|c|c|c|c|c|c|c|c|}
\hline Vegetation & $\begin{array}{c}\text { Bulk } \\
\text { density }\end{array}$ & $\mathrm{C}$ & $\mathbf{N}$ & $\delta^{13} \mathrm{C}$ & $\begin{array}{c}\% \text { of } \\
\text { original } \\
\text { prairie C } \\
\text { remaining } \\
\end{array}$ & $\begin{array}{c}\text { Amount } \\
\text { of tree C } \\
\text { accumulated }\end{array}$ & MRT \\
\hline & $\mathrm{g} \mathrm{cm}^{-3}$ & \multicolumn{3}{|c|}{$-\mathrm{Mg} \mathrm{ha}^{-1}$} & & $\mathrm{Mg} \mathrm{ha}^{-1}$ & $\mathrm{yr}$ \\
\hline \multicolumn{8}{|c|}{$\underline{0-5 \mathrm{~cm}}$} \\
\hline Cedar old & $1.04^{\mathrm{a}}$ & $6.43^{b}$ & $0.65^{c}$ & $-23.31^{d}$ & 82.03 & 3.42 & 278 \\
\hline Cedar young & $1.16^{\mathrm{b}}$ & $3.70^{\mathrm{a}}$ & $0.61^{b c}$ & $-21.15^{b}$ & 78.19 & 0.83 & 102 \\
\hline Mixed & $1.23^{b c}$ & $4.36^{\mathrm{a}}$ & $0.55^{\mathrm{bc}}$ & $-21.92^{c}$ & 79.12 & 1.46 & 107 \\
\hline Pine & $1.28^{\mathrm{C}}$ & $4.06^{\mathrm{a}}$ & $0.34^{\mathrm{a}}$ & $-23.74^{d}$ & 45.03 & 2.41 & 90 \\
\hline Prairie & $1.13^{\mathrm{ab}}$ & $3.67^{\mathrm{a}}$ & $0.44^{\mathrm{ab}}$ & $-19.63^{a}$ & & & \\
\hline \multicolumn{8}{|c|}{$\underline{5-15 \mathrm{~cm}}$} \\
\hline Cedar old & $1.32^{\mathrm{a}}$ & $6.64^{\mathrm{bc}}$ & $0.87^{b c}$ & $-20.38^{\mathrm{C}}$ & 69.48 & 1.66 & 151 \\
\hline Cedar young & $1.31^{\mathrm{a}}$ & $6.22^{b c}$ & $0.75^{b}$ & $-19.16^{b}$ & 77.86 & 0.64 & 100 \\
\hline Mixed & $1.33^{\mathrm{a}}$ & $5.82^{\mathrm{b}}$ & $0.74^{b}$ & $-19.36^{b}$ & 70.89 & 0.74 & 73 \\
\hline Pine & $1.44^{\mathrm{b}}$ & $4.61^{\mathrm{a}}$ & $0.55^{\mathrm{a}}$ & $-22.24^{d}$ & 33.82 & 2.19 & 66 \\
\hline Prairie & $1.36^{\mathrm{ab}}$ & $7.17^{\mathrm{c}}$ & $0.93^{\mathrm{c}}$ & $-18.31^{\mathrm{a}}$ & & & \\
\hline \multicolumn{8}{|c|}{$\underline{15-30 \mathrm{~cm}}$} \\
\hline Cedar old & $1.45^{\mathrm{a}}$ & $6.97^{b}$ & $0.78^{\mathrm{b}}$ & $-18.28^{\mathrm{C}}$ & 81.89 & 1.11 & 275 \\
\hline Cedar young & $1.40^{\mathrm{a}}$ & $6.63^{\mathrm{b}}$ & $0.79^{b}$ & $-17.47^{b}$ & 85.48 & 0.51 & 159 \\
\hline Mixed & $1.40^{\mathrm{a}}$ & $6.58^{\mathrm{b}}$ & $0.76^{b}$ & $-18.00^{b c}$ & 79.91 & 0.86 & 111 \\
\hline Pine & $1.53^{b}$ & $4.48^{\mathrm{a}}$ & $0.44^{\mathrm{a}}$ & $-20.92^{d}$ & 35.94 & 1.91 & 70 \\
\hline Prairie & $1.42^{\mathrm{a}}$ & $7.16^{\mathrm{b}}$ & $0.96^{\mathrm{C}}$ & $-16.71^{\mathrm{a}}$ & & & \\
\hline
\end{tabular}

+ Mean residence times (MRTs) based on $55 \mathrm{yr}$ for cedars, $72 \mathrm{yr}$ for pines and $25 \mathrm{yr}$ for mixed and young sites. Means followed by different superscript letters differed significantly at $p<0.05$.

differences are not as large. These trends coincided with a change in cations, especially $\mathrm{Ca}$ in the upper layer of cedar and mixed soils when compared with prairie and pine soils. The higher measured available P content in the two upper depth increments of the pine soils could be associated with the drop in $\mathrm{pH}$ or changes in Ca content through root uptake at those depths (Table 4).

The analysis of cations in the litter showed cedar litter to contain more $\mathrm{Ca}$ than pine or prairie. All other nutrient ions $(\mathrm{Mg}, \mathrm{P}$, and $\mathrm{K})$ were not significantly different for pine and cedar litter with prairie litter containing less of all nutrient ions (Table 5). Analysis of the vegetation showed three- to five-fold higher concentrations of $\mathrm{Ca}$ in the needles and branches of the cedar compared with pine. The other nutrient elements sampled $(\mathrm{K}$,

Table 2. Plant biomass C, litter C, soil profile C, ecosystem C, and $C$ accrual per year under stands of old cedar, young cedar, mixed (cedar and pine), pine, and prairie at the Nebraska National Forest at Halsey, NE. +

\begin{tabular}{|c|c|c|c|c|c|}
\hline Vegetation & Biomass C & Litter C & Soil C & Ecosystem C $\neq$ & C accrual§ \\
\hline & \multicolumn{4}{|c|}{$\mathrm{Mg} \mathrm{ha}^{-1}$} & $\mathrm{Mg} \mathrm{ha}^{-1} \mathrm{yr}^{-1}$ \\
\hline Cedar old & 51.4 & $9.85^{b}$ & $37.0^{\mathrm{c}}$ & 98.2 & 1.12 \\
\hline Cedar young & & $7.37^{b}$ & $30.5^{b}$ & & \\
\hline Mixed & & $14.2^{\mathrm{c}}$ & $30.1^{b}$ & & \\
\hline Pine & 87.6 & $23.6^{d}$ & $25.1^{\mathrm{a}}$ & 136 & 1.38 \\
\hline Prairie & 9.79 & $1.3^{\mathrm{a}}$ & $32.5^{b}$ & 36.5 & \\
\hline
\end{tabular}

+ Means followed by different superscript letters differed significantly at $p<0.05$. ₹ To depth of $1 \mathrm{~m}$ corrected for equivalent weight of the prairie profile. $\S$ Accrual based on $55 \mathrm{yr}$ for cedar and $72 \mathrm{yr}$ for ponderosa pine.

I Estimated from Burke et al. (2008). 
Table 3. Plant biomass, litter, soil profile, ecosystem N, accrual per year, and litter and soil $\mathrm{C}$ to $\mathrm{N}$ ratios under stands of old cedar, young cedar, mixed (cedar and pine), pine and prairie at the Nebraska National Forest at Halsey, NE. $t$

\begin{tabular}{|c|c|c|c|c|c|c|c|}
\hline Vegetation & Biomass $\mathrm{N}$ & Litter $\mathbf{N}$ & Litter $\mathrm{C} / \mathrm{N}$ & Soil N‡ & Soil C/N & Ecosystem N & $\mathrm{N}$ accrual§ \\
\hline & $\mathrm{Mg} \mathrm{ha}^{-1}$ & $\mathrm{Mg} \mathrm{ha}^{-1}$ & & $\mathrm{Mg} \mathrm{ha}^{-1}$ & & $\mathrm{Mg} \mathrm{ha}^{-1}$ & $\mathrm{Mg} \mathrm{ha}^{-1} \mathrm{yr}^{-1}$ \\
\hline Cedar old & 0.408 ฯ & $0.39^{c}$ & $25.70^{\mathrm{a}}$ & $3.86^{b c}$ & $10.18^{b}$ & 4.66 & 0.011 \\
\hline Cedar young & & $0.21^{b}$ & $33.86^{b c}$ & $3.57^{b c}$ & $8.56^{\mathrm{a}}$ & & \\
\hline Mixed & & $0.42^{\mathrm{C}}$ & $33.19^{b}$ & $3.42^{b}$ & $8.88^{\mathrm{a}}$ & & \\
\hline Pine & $0.331 \#$ & $0.66^{d}$ & $34.90^{\mathrm{bc}}$ & $2.37^{\mathrm{a}}$ & $10.83^{b}$ & 3.36 & -0.010 \\
\hline Prairie & $0.062+\dagger$ & $0.04^{\mathrm{a}}$ & $36.81^{c}$ & $3.95^{\mathrm{c}}$ & $8.32^{\mathrm{a}}$ & 4.05 & \\
\hline
\end{tabular}

+ Means followed by different superscript letters differed significantly at $p<0.05$.

‡ To depth of $1 \mathrm{~m}$ corrected for equivalent weight of the prairie profile.

$\S$ Accrual based on $55 \mathrm{yr}$ for cedar and $72 \mathrm{yr}$ for ponderosa pine.

I Estimated based on values from Norris et al. (2001b).

\# Estimated based on values from (Kaye et al. 2005).

†† Estimated from Burke et al. (2008).

$\mathrm{Mg}$, and $\mathrm{P}$ ) did not differ between trees but again were concentrated in the needles and branches rather than the bole (Table 6).

\section{Relationships of Soil Carbon and Nitrogen Pools to Soil Chemistry}

Structural analysis produced statistically significant models describing the relationship of soil $\mathrm{C}$ and $\mathrm{N}$ content to other variables measured; however, the strength and contributing characteristics differed depending on vegetation type (Table 7). The analysis of the old cedar soils produced the strongest model with $85 \%$ of the variation in soil $\mathrm{N}$ best described by $\mathrm{Ca}$ and $\mathrm{K}$ and $90 \%$ of the variation in soil $\mathrm{C}$ described by $\mathrm{Ca}, \mathrm{N}$, and $\mathrm{Mg}$ (Fig. 1). The model strength for $\mathrm{C}$ and $\mathrm{N}$ based on the soil chemistries sampled was lower for other vegetation types (Table 7). In general, $\mathrm{C}$ was more strongly described for cedar sites (old ce-

Table 4. Soil pH, cation content, and $\mathrm{P}$ from soils under stands of old cedar, young cedar, mixed (cedar and pine), pine and from prairie soils at the Nebraska National Forest at Halsey, $\mathrm{NE}$, for each depth of 0 to 5,5 to 15 , and 15 to $30 \mathrm{~cm}$. +

\begin{tabular}{|c|c|c|c|c|c|}
\hline Vegetation & $\mathrm{pH}$ & $\mathrm{Ca}$ & K & Mg & $\mathbf{P}$ \\
\hline & & \multicolumn{4}{|c|}{$\mathrm{kg} \mathrm{ha}^{-1}$} \\
\hline \multicolumn{6}{|c|}{$\underline{0-5 \mathrm{~cm}}$} \\
\hline Cedar old & $7.12^{d}$ & $624.51^{d}$ & $79.02^{\mathrm{c}}$ & $60.15^{\mathrm{cd}}$ & $4.15^{\mathrm{ab}}$ \\
\hline Cedar young & $6.37^{\mathrm{C}}$ & $407.72^{\mathrm{c}}$ & $65.37^{b}$ & $54.80^{\mathrm{bc}}$ & $3.86^{\mathrm{a}}$ \\
\hline Mixed & $6.30^{c}$ & $463.75^{\mathrm{C}}$ & $75.43^{\mathrm{c}}$ & $68.13^{d}$ & $4.82^{b}$ \\
\hline Pine & $4.98^{\mathrm{a}}$ & $237.01^{\mathrm{a}}$ & $46.50^{\mathrm{a}}$ & $53.16^{\mathrm{b}}$ & $9.59^{c}$ \\
\hline Prairie & $5.72^{b}$ & $308.96^{\mathrm{b}}$ & $65.00^{\mathrm{b}}$ & $46.23^{\mathrm{a}}$ & $4.30^{\mathrm{ab}}$ \\
\hline \multicolumn{6}{|c|}{$\underline{5-15 \mathrm{~cm}}$} \\
\hline Cedar old & $6.28^{\mathrm{b}}$ & $684.09^{b}$ & $160.95^{c}$ & $134.55^{\mathrm{C}}$ & $7.95^{b}$ \\
\hline Cedar young & $5.88^{\mathrm{a}}$ & $567.37^{b}$ & $129.65^{b}$ & $117.27^{a b}$ & $7.37^{\mathrm{ab}}$ \\
\hline Mixed & $5.69^{\mathrm{a}}$ & $625.45^{\mathrm{ab}}$ & $133.50^{b}$ & $121.45^{b}$ & $7.04^{\mathrm{ab}}$ \\
\hline Pine & $5.68^{\mathrm{a}}$ & $534.17^{a}$ & $90.53^{\mathrm{a}}$ & $119.04^{\mathrm{ab}}$ & $10.84^{c}$ \\
\hline Prairie & $5.85^{\mathrm{a}}$ & $722.53^{b}$ & $130.92^{b}$ & $105.09^{a}$ & $6.30^{\mathrm{a}}$ \\
\hline \multicolumn{6}{|c|}{$\underline{15-30 \mathrm{~cm}}$} \\
\hline Cedar old & $5.54^{\mathrm{a}}$ & $589.57^{a}$ & $206.49^{c}$ & $198.31^{\mathrm{C}}$ & $13.59^{\circ}$ \\
\hline Cedar young & $5.54^{\mathrm{a}}$ & $706.38^{\mathrm{ab}}$ & $160.55^{b}$ & $161.44^{\mathrm{ab}}$ & $10.24^{b}$ \\
\hline Mixed & $5.51^{\mathrm{a}}$ & $942.08^{\mathrm{C}}$ & $175.37^{b c}$ & $171.12^{b}$ & $9.30^{\mathrm{b}}$ \\
\hline Pine & $5.98^{b}$ & $858.57^{b c}$ & $131.43^{a}$ & $157.83^{a b}$ & $10.31^{b}$ \\
\hline Prairie & $6.15^{b}$ & $1057.15^{c}$ & $164.13^{b}$ & $147.23^{\mathrm{a}}$ & $6.37^{a}$ \\
\hline
\end{tabular}

† Means followed by different superscript letters differed significantly at $p<0.05$. dar, young cedar, all cedar) with squared multiple correlations of $0.88,0.43$, and 0.74 , respectively. The $\mathrm{N}$ content was more strongly described for sites with pine (pine, mixed, and all pine) with squared multiple correlations of $0.72,0.56,0.68$, and the prairie with 0.842 (Table 7).

\section{Microbial Analysis and Relationship to Soil and Litter Chemistry}

Analysis of microbial fatty acids found in the litter showed that the cedar litter contained more microbial markers in almost every category, including the ubiquitous fatty acid 16:0 (Table 8 ). The sum of the fatty acids can be used to estimate total microbial biomass with $410 \mathrm{nmol} \mathrm{g}^{-1}$ in the cedar, 358 in the pine, and 295 in the prairie litter. Cedar litter also contained significant amounts of the marker for arbuscular mycorrhizal fungi (16:1 $\omega 5 c)$ showing that hyphae and/or roots colonized by arbuscular mycorrhizal fungi have permeated the litter layer. The lack of this marker in the prairie litter suggests that the roots and arbuscular mycorrhizal hyphae remain largely in the mineral soil.

Litter FAME profiles separated out by vegetation type when analyzed by PCA explained nearly $60 \%$ of the variability within the FAME data set (33.0\% for PC 1 and 26.5\% for PC 2) (Fig. 2). Compared with pine and prairie litter, cedar litter was enriched in several gram-positive (iso-branched) bacterial fatty acids and the arbuscular mycorrhizal fungal biomarker (16:1 $1 \omega 5 \mathrm{c})$. Cedar FAME profiles were also strongly correlated with soil $\mathrm{Mg}$ and $\mathrm{Ca}$ contents; these nutrients had Pearson correlation values of -0.798 and -0.779 , respectively, for PC 1 . With regards to PC 2 , soil $\mathrm{pH}$ had the greatest Pearson correlation with PC $2(r=-0.912)$ and

Table 5. Cation content in $\mathrm{kg} \mathrm{ha}^{-1}$ for litter (O Layer) under stands of cedar, pine, and in prairie at the Nebraska National Forest at Halsey, NE. +

\begin{tabular}{lcrrr} 
Vegetation & $\mathbf{C a}$ & $\mathbf{K}$ & $\mathbf{M g}$ & $\mathbf{P}$ \\
\hline Cedar & $124.9^{\mathrm{a}}$ & $56.2^{\mathrm{a}}$ & $66.0^{\mathrm{a}}$ & $24.4^{\mathrm{a}}$ \\
Pine & $67.4^{\mathrm{b}}$ & $61.7^{\mathrm{a}}$ & $80.6^{\mathrm{a}}$ & $25.7^{\mathrm{a}}$ \\
Prairie & $49.0^{\mathrm{b}}$ & $6.9^{\mathrm{b}}$ & $5.5^{\mathrm{b}}$ & $1.9^{\mathrm{a}}$ \\
\hline
\end{tabular}

+ Means followed by different superscript letters differed significantly at $p<0.05$. 
was positively associated with the cedar and prairie FAME profiles and negatively associated with the pine FAME profiles.

\section{DISCUSSION}

We hypothesized that $\mathrm{C}$ content under cedar and pine would differ from that of the native prairies and that the impacts on SOC would differ for each species planted. We found significant differences in the amount of SOC stored, the rate of storage, and the location of stored SOC as a consequence of tree type planted. Cedar had greater SOC content through the profile, while the pine had less $\mathrm{C}$ in the soil and greater amounts of $\mathrm{C}$ stored in litter on the surface. While it is not surprising that litter incorporation may differ for these species it is important to identify what influences the rate at which tree $\mathrm{C}$ becomes SOC so that vegetation effects may be more accurately modeled.

In addition to evaluating the amount and location of $\mathrm{C}$ stored under cedar and pine, our study also allowed the amount of $\mathrm{C}$ remaining from the former land use type, prairie, to be identified. On our site, the pine soils lost over half the prairie $\mathrm{C}$ and replaced a portion of it with pine $C$. In contrast, cedars have
Table 6. Cation content (\%) of trunk, needles, and branches of cedar and pine trees at the Nebraska National Forest at Halsey, NE. $†$

\begin{tabular}{lccccc} 
Tree Section & Vegetation & $\mathbf{C a}$ & $\mathbf{K}$ & $\mathbf{M g}$ & $\mathbf{P}$ \\
\hline Bole & Cedar & $0.08^{\mathrm{a}}$ & $0.02^{\mathrm{a}}$ & $0.00^{\mathrm{a}}$ & $0.01^{\mathrm{a}}$ \\
& Pine & $0.09^{\mathrm{a}}$ & $0.05^{\mathrm{a}}$ & $0.02^{\mathrm{a}}$ & $0.01^{\mathrm{a}}$ \\
\multirow{3}{*}{ Old Needles } & Cedar & $1.76^{\mathrm{a}}$ & $0.32^{\mathrm{a}}$ & $0.14^{\mathrm{a}}$ & $0.07^{\mathrm{a}}$ \\
& Pine & $0.31^{\mathrm{b}}$ & $0.35^{\mathrm{a}}$ & $0.11^{\mathrm{a}}$ & $0.09^{\mathrm{a}}$ \\
Young Needles & Cedar & $1.40^{\mathrm{a}}$ & $0.22^{\mathrm{a}}$ & $0.09^{\mathrm{a}}$ & $0.05^{\mathrm{a}}$ \\
& Pine & $0.33^{\mathrm{b}}$ & $0.25^{\mathrm{a}}$ & $0.09^{\mathrm{a}}$ & $0.06^{\mathrm{a}}$ \\
\multirow{2}{*}{ Inner Branch } & Cedar & $1.37^{\mathrm{a}}$ & $0.18^{\mathrm{a}}$ & $0.08^{\mathrm{a}}$ & $0.05^{\mathrm{a}}$ \\
& Pine & $0.33^{\mathrm{b}}$ & $0.20 \mathrm{a}$ & $0.08^{\mathrm{a}}$ & $0.05^{\mathrm{a}}$ \\
Middle Branch & Cedar & $1.06^{\mathrm{a}}$ & $0.20^{\mathrm{a}}$ & $0.07^{\mathrm{a}}$ & $0.05^{\mathrm{a}}$ \\
& Pine & $0.34^{\mathrm{b}}$ & $0.22 \mathrm{a}$ & $0.07^{\mathrm{a}}$ & $0.05^{\mathrm{a}}$ \\
Outer Branch & Cedar & $1.37^{\mathrm{a}}$ & $0.21^{\mathrm{a}}$ & $0.08^{\mathrm{a}}$ & $0.05^{\mathrm{a}}$ \\
& Pine & $0.41^{\mathrm{b}}$ & $0.14^{\mathrm{a}}$ & $0.06^{\mathrm{a}}$ & $0.05^{\mathrm{a}}$ \\
\hline
\end{tabular}

+ Means followed by different superscript letters differed significantly at $p<0.05$.

added $\mathrm{C}$ to the soil while retaining $82 \%$ of the original prairie $\mathrm{C}$. The young and old cedar have retained approximately the same amount of prairie soil $\mathrm{C}$ suggesting that losses in the cedar stands

Table 7. Squared multiple correlations from structural analysis using Amos for $\mathrm{C}$ and $\mathrm{N}$, and $\mathrm{C}$ with $\mathrm{N}$, as a model component for predicting $C$ for each area (old cedar, young cedar, mixed (cedar and pine), pine and prairie) and each vegetation type (all cedars, all pines) at the Nebraska National Forest, NE.†

\begin{tabular}{|c|c|c|c|}
\hline Model & Squared mean correlation & Drivers & Allowed to covary in Model \\
\hline \multicolumn{4}{|l|}{ Cedar old } \\
\hline $\mathrm{C}$ & 0.878 & $\mathrm{Ca}$ & \multirow{3}{*}{$\begin{array}{c}\mathrm{Ca}<->\mathrm{Mg}, \mathrm{Ca}<->\mathrm{pH}, \mathrm{pH}<->\mathrm{K} \\
\mathrm{Mg}<->\mathrm{pH}, \mathrm{Mg}<->\mathrm{K}, \mathrm{Ca}<->\mathrm{K}, \mathrm{Ca}<->\mathrm{P}\end{array}$} \\
\hline $\mathrm{N}$ & 0.854 & $\mathrm{Ca}, \mathrm{K}$ & \\
\hline $\mathrm{C}$ with $\mathrm{N}$ driver & 0.901 & $\mathrm{Ca}, \mathrm{N}, \mathrm{Mg} *$ & \\
\hline \multicolumn{4}{|l|}{ Cedar young } \\
\hline C & 0.425 & $M g^{*}$ & \multirow[t]{3}{*}{$\mathrm{K}<->\mathrm{Mg}, \mathrm{K}<->\mathrm{Ca}$} \\
\hline $\mathrm{N}$ & 0.406 & $\mathrm{Ca}, \mathrm{Mg}^{*}$ & \\
\hline $\mathrm{C}$ with $\mathrm{N}$ driver & 0.638 & $\mathrm{~N}, \mathrm{pH}, \mathrm{Ca}^{*}$ & \\
\hline \multicolumn{4}{|l|}{ Mixed } \\
\hline $\mathrm{C}$ & 0.366 & $\mathrm{Ca}, \mathrm{Mg}$, & \multirow{3}{*}{$\begin{array}{c}\mathrm{Ca}<->\mathrm{Mg}, \mathrm{Ca}<->\mathrm{pH}, \mathrm{pH}<->\mathrm{K} \\
\mathrm{Mg}<->\mathrm{pH}, \mathrm{Mg}<->\mathrm{K}, \mathrm{Ca}<->\mathrm{K}, \mathrm{Mg}<->\mathrm{P}\end{array}$} \\
\hline $\mathrm{N}$ & 0.559 & $\mathrm{Ca}, \mathrm{K}, \mathrm{P}, \mathrm{Mg}^{*}$ & \\
\hline $\mathrm{C}$ with $\mathrm{N}$ driver & 0.563 & $\mathrm{Ca}, \mathrm{N}, \mathrm{P}$ & \\
\hline \multicolumn{4}{|l|}{ Pine } \\
\hline C & 0.281 & $\mathrm{~K}^{*}, \mathrm{pH}^{*}$ & \multirow{3}{*}{$\begin{array}{c}\mathrm{Mg}<->\mathrm{pH}, \mathrm{Mg}<->\mathrm{K}, \mathrm{pH}<->\mathrm{K} \\
\mathrm{Mg}<->\mathrm{P}, \mathrm{Ca}<->\mathrm{Mg}, \mathrm{Ca}<->p H+\end{array}$} \\
\hline $\mathrm{N}$ & 0.715 & $\mathrm{~K}, \mathrm{Ca}^{*}, \mathrm{P}^{*}$ & \\
\hline $\mathrm{C}$ with $\mathrm{N}$ driver & 0.313 & $\mathrm{~K}^{*}, \mathrm{P}^{*}, \mathrm{pH}^{*}$ & \\
\hline \multicolumn{4}{|l|}{ Prairie } \\
\hline $\mathrm{C}$ & 0.255 & $\mathrm{~K}^{*}$ & \multirow{3}{*}{$\begin{array}{c}\mathrm{Mg}<->\mathrm{pH}, \mathrm{Mg}<->\mathrm{K}, \mathrm{pH}<->\mathrm{K} \\
\mathrm{Mg}<->\mathrm{P}, \mathrm{Ca}<->\mathrm{Mg}\end{array}$} \\
\hline $\mathrm{N}$ & 0.842 & $\mathrm{Ca}, \mathrm{K}$ & \\
\hline $\mathrm{C}$ with $\mathrm{N}$ driver & 0.419 & $\mathrm{Ca}, \mathrm{N}$ & \\
\hline \multicolumn{4}{|l|}{ All Cedar } \\
\hline $\mathrm{C}$ & 0.743 & $\mathrm{Ca}, \mathrm{pH}, \mathrm{P}, \mathrm{Mg}$, & \multirow{3}{*}{$\begin{array}{c}\mathrm{Ca}<->\mathrm{Mg}, \mathrm{Ca}<->\mathrm{pH}, \mathrm{pH}<->\mathrm{K}, \\
\mathrm{Mg}<->\mathrm{pH}, \mathrm{Mg}<->\mathrm{K}, \mathrm{Ca}<->\mathrm{K}, \mathrm{Ca}<->\mathrm{P},\end{array}$} \\
\hline$N$ & 0.293 & K, Ca & \\
\hline $\mathrm{C}$ with $\mathrm{N}$ driver & 0.757 & $\mathrm{Ca}, \mathrm{pH}, \mathrm{Mg}, \mathrm{P}$ & \\
\hline \multicolumn{4}{|l|}{ All Pine } \\
\hline $\mathrm{C}$ & 0.057 & No significant drivers & $\mathrm{Mg}<->\mathrm{K}, \mathrm{Ca}<->\mathrm{pH}, \mathrm{Ca}<->\mathrm{P}$ \\
\hline $\mathrm{N}$ & 0.675 & $\mathrm{~K}, \mathrm{Ca}, \mathrm{Mg}$ & \\
\hline $\mathrm{C}$ with $\mathrm{N}$ driver & 0.099 & No significant drivers & \\
\hline
\end{tabular}

+ The soil chemical constituents that contributed significantly $(p<0.05)$ or marginally* $(0.10>p>0.05)$ to the models developed for $\mathrm{C}$ and $\mathrm{N}$ for each site and vegetation group are listed as drivers. Soil characteristics allowed to covary in the models tested are also identified.

₹ Each of the pairs of soil chemical constituents that were allowed to covary (critical ratio $>1.282$ in analysis of covariance) within the model tested is also listed. The exception to this rule is where $\mathrm{Ca}$ and $\mathrm{pH}$ were allowed to covary in the pine area. Both $\mathrm{Ca}$ and pH significantly covaried with area (stand level variation). Adding the $\mathrm{Ca}<->\mathrm{pH}$ covariance was necessary to produce a reasonable model when area was removed. 


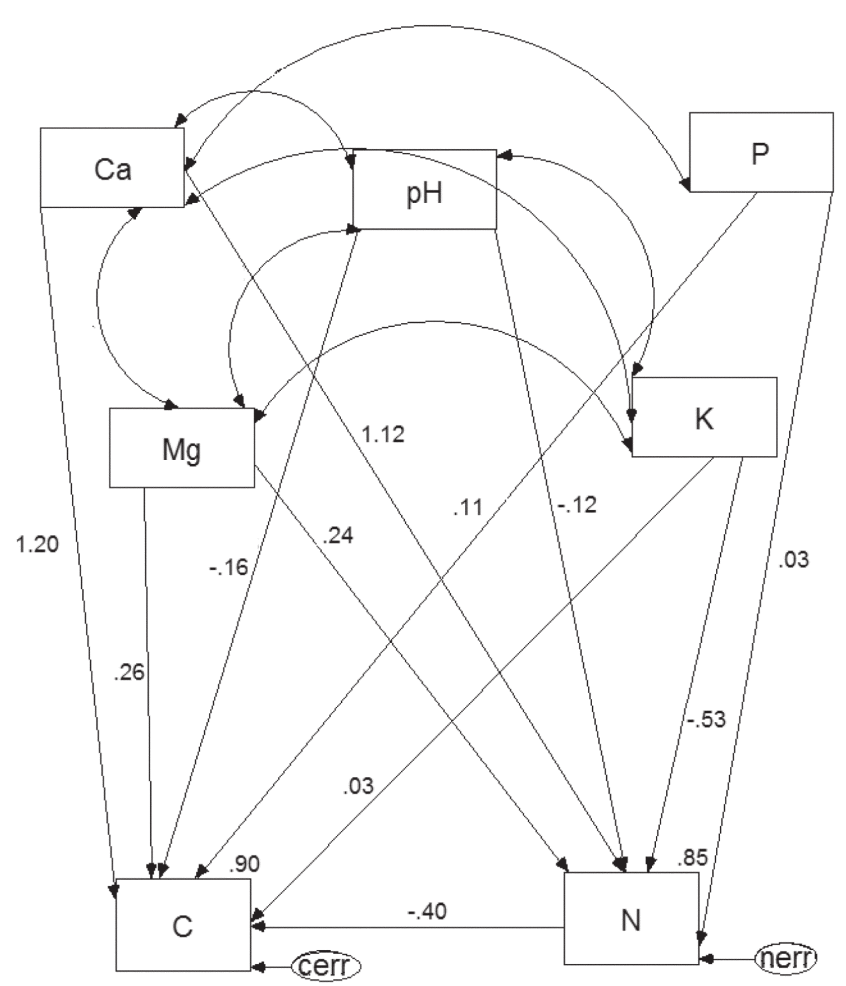

Fig. 1. Structural equation model produced for $\mathrm{C}$ and $\mathrm{N}$ for the old cedar sites at the Nebraska National Forest at Halsey, NE. Curved lines indicate soil chemical properties that were allowed to covary within the model. Straight lines indicate the relationships that were tested for $\mathrm{C}$ and $\mathrm{N}$ in old cedar soils. The values on the straight lines are the standardized regression coefficients that describe the indicated relationship. The overall relationship is indicated by the squared multiple correlations for $\mathrm{C}$ and $\mathrm{N}$ which appear on the upper right hand corner of each of those boxes.

occurred soon after planting. It is possible on these sites that this may represent loss due to initial disturbance. Cedar stands appeared to add and stabilize $\mathrm{C}$ more as they aged. That half of the $\mathrm{C}$ under cedars was derived from trees is consistent with the findings of Hernandez-Ramirez et al. (2011) where they found that half of the $\mathrm{C}$ in their afforested soils was tree $\mathrm{C} 35 \mathrm{yr}$ following plantation; however, their study found increases in SOC stocks under conifers on fine textured soils.

The assumptions used in calculating the proportion of prairie SOC and its MRT under the two different trees can affect the interpretation of the data. The study by Wynn and Bird (2007) that found that $\mathrm{C}_{4}$ vegetation decomposed much more rapidly than $\mathrm{C}_{3}$ material was based on $\mathrm{C}_{3}$ tree versus $\mathrm{C}_{4}$ grasses. Our study involved the decomposition of $\mathrm{SOC}$ derived from prairie grasses. It has long been established that the different litter quality as designated by lignin to $\mathrm{N}$ ratios in the Century model have a major effect on decomposition rates. We recently found that $\mathrm{C}_{3}$ wheat residues under incubation decomposed more rapidly than $\mathrm{C}_{4}$ maize (Birgé, 2013). In terms of our calculations, we assumed that both $\mathrm{C}_{3}$ and $\mathrm{C}_{4}$ derived SOC decompose at the same rate. The $\delta^{13} \mathrm{C}$ content of this sandy prairie was found to be $-19.6 \%$ at the surface and $-16.7 \%$ at depth. These values are not as negative as an equivalent native prairie on a $23 \%$ clay soil $(-16.1 \%$ at the surface and $-14.7 \%$ at depth) (Follett et al., 1997). Werth and Kuzyakov (2010) found in their com-
Table 8. Amount of fatty acids (nmol $\mathrm{g}^{-1}$ ) found in the litter layer under stands of cedar, pine, and prairie at the Nebraska National Forest at Halsey, NE. +

\begin{tabular}{cccc} 
Fatty Acid $\neq$ & Cedar & Pine & Prairie \\
\hline Bacteria & & & \\
$15: 0$ & $7.3^{\mathrm{a}}$ & $6.2^{\mathrm{b}}$ & $6.7^{\mathrm{ab}}$ \\
$17: 0$ & $7.4^{\mathrm{a}}$ & $7.3^{\mathrm{a}}$ & $7.8^{\mathrm{a}}$ \\
$18: 0$ & $30.4^{\mathrm{a}}$ & $28.4^{\mathrm{a}}$ & $20.0^{\mathrm{b}}$
\end{tabular}

Gram Pos. Bacteria

$\begin{array}{lrrr}i 14: 0 & 8.7^{\mathrm{a}} & 2.3^{\mathrm{b}} & 2.2^{\mathrm{b}} \\ i 15: 0 & 13.0^{\mathrm{a}} & 9.4^{\mathrm{a}} & 8.6^{\mathrm{a}} \\ \mathrm{a} 15: 0 & 13.7^{\mathrm{a}} & 6.5^{\mathrm{c}} & 10.9^{\mathrm{b}} \\ i 16: 0 & 13.6^{\mathrm{a}} & 9.5^{\mathrm{b}} & 6.9^{\mathrm{b}} \\ \mathrm{i} 17: 0 & 3.7^{\mathrm{a}} & 2.3^{\mathrm{b}} & 1.9^{\mathrm{b}} \\ \mathrm{a} 17: 0 & 6.7^{\mathrm{b}} & 9.4^{\mathrm{a}} & 5.3^{\mathrm{b}}\end{array}$

Gram Neg. Bacteria

cy17:0 $\omega 7-8$
cy19:0 $\omega 9-10$
cy19:0 $\omega 7-8$
16:1 $\omega 7 \mathrm{C}$
Fungi

$\begin{array}{ll}18: 2 \omega 6,9 \mathrm{c} & 78.2^{\mathrm{a}} \\ 18: 1 \omega 9 \mathrm{c} & 51.6^{\mathrm{a}}\end{array}$

Gram Neg. Bacteria \& AM Fungi

$\begin{array}{llll}18: 1 \omega 7 \mathrm{c} & 17.8^{\mathrm{c}} & 32.0^{\mathrm{b}} & 47.3^{\mathrm{a}} \\ \text { AM Fungi } & & & \end{array}$

\begin{tabular}{lccc} 
16:1 w5c & $15.5^{\mathrm{a}}$ & $2.6^{\mathrm{b}}$ & \\
$\begin{array}{l}\text { Ubiquitous Fatty Acid } \\
\text { 16:0 }\end{array}$ & $75.5^{\mathrm{a}}$ & $69.0^{\mathrm{a}}$ & $48.3^{\mathrm{b}}$ \\
$\begin{array}{l}\text { Unknown } \\
14: 0\end{array}$ & $53.9^{\mathrm{a}}$ & $44.1^{\mathrm{b}}$ & $15.2^{\mathrm{c}}$ \\
\hline
\end{tabular}

+ Means followed by different superscript letters differed significantly at $p<0.05$.

\# Fatty acid methyl esters were assigned as biomarkers of specific microbial populations according to Vestal and White (1989), Zak et al. (1996), Bossio and Scow (1998), Bååth (2003), Högberg et al. (2007), and Olsson et al. (1995).

prehensive review of the discriminations between ${ }^{13} \mathrm{C}$ and ${ }^{12} \mathrm{C}$ that occur during translocation of photosynthate to the root and root respiration results in an enrichment of ${ }^{13} \mathrm{C}$ of an average of $1.2 \%$. We did not consider this in our calculations that were based on a measured litter ${ }^{13} \mathrm{C}$ content of $-26.6 \%$ used in the end member calculations for all depths. Plant components especially the fatty acids and lignins can be considerably more negative than the more decomposable cellulose and amino acids (Boutton, 1996). Paul et al. (2011) found that the nonhydrolyzable SOC was on average $4 \%$ more negative than the total soil. Each passage through a member of the soil food web also results in discrimination, a factor often used in explanation of the $~ 3 \%$ o difference with depth. An additional explanation could involve a change in $\mathrm{C}_{3}-\mathrm{C}_{4}$ prairie-species composition with past climate changes (Follett et al., 1997). On average, the ${ }^{13} \mathrm{C}$-SOC signal in the majority of soils is similar enough to that of the associated vegetation such that this calculation can be employed (Boutton, 1996). Our study was based on one soil type and two closely related species with identical ${ }^{13} \mathrm{C}$ signals planted at approximately the same time. This allowed us to conduct a comparative analysis 


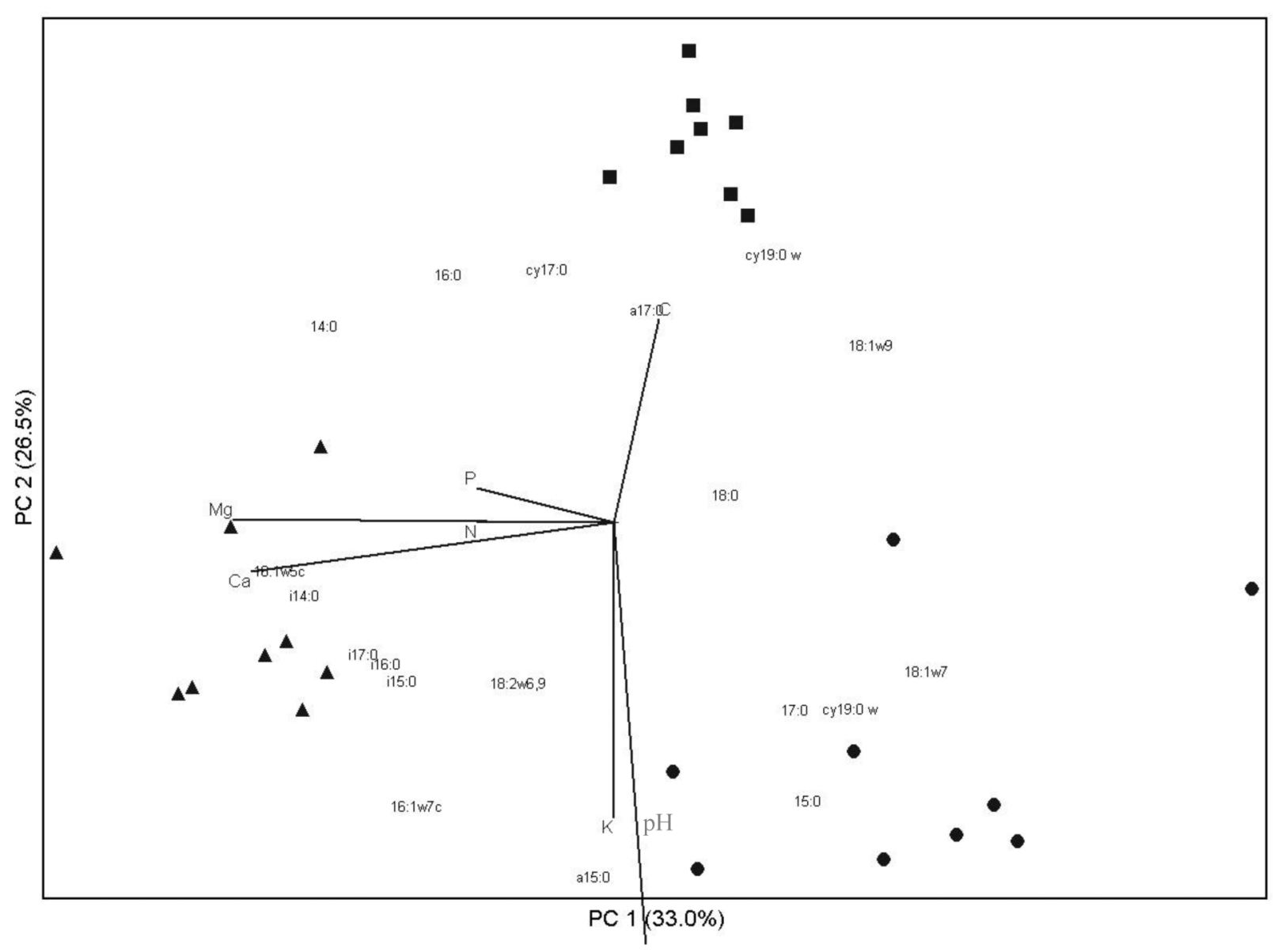

Fig. 2. Principal components analysis of cedar (solid triangles), pine (solid squares), and prairie (solid circles) litter FAMEs (fatty acid methyl esters). The percent variance explained by each PC is shown in parentheses. Also shown are correlations of individual FAMEs and correlation vectors of soil $\mathrm{pH}$ and nutrients, with litter FAME profiles.

of the contribution of the tree species and the MRT of the remaining native prairie soil.

Poeplau et al. (2011) examined soil C accrual following conversion of grasslands to forest. Their study only found accrual of $\mathrm{C}$ when the forest floor $\mathrm{C}$ content was included in the soil C estimates. In our study, the litter in the pine ecosystem represented a $\mathrm{C}$ sink; however, in general surface litter $\mathrm{C}$ is less protected from disturbance than $\mathrm{SOC}$ and may be rapidly lost to the atmosphere through fire or other disturbance. The cedar litter, unlike the pine litter, enriched the SOC pools to a depth of at least $30 \mathrm{~cm}$ stabilizing a greater $\mathrm{SOC}$ pool. Our findings regarding stabilization of $\mathrm{C}$ following pine afforestation are not unique. Berthrong et al. (2009), using a meta-analysis approach, detected a consistent pattern of $\mathrm{C}$ loss associated with pine afforestation. However, we can go beyond just SOC contents to evaluate the mechanisms that underlie these different patterns in storage.

Our second hypothesis was that the importance of soil chemistry controls and soil microbiota for SOC accrual would differ under these tree species. We predicted that increased levels of $\mathrm{Ca}$ and associated changes in litter microbiota would result in greater prairie $\mathrm{C}$ retention and SOC contents in the cedar soils than the pine, especially at depth. The differences in ${ }^{13} \mathrm{C} \mathrm{SOC}$ content with depth for cedar versus pine relative to the original native prairie (Table 1) suggests differences in the amount of litter and root in- corporation across the soil depths evaluated. It also represents differences in the amount of prairie $\mathrm{C}$ stabilized at these different depths in agreement with Oades (1988). Path analysis showed Ca to be a driver of soil $\mathrm{C}$ in the cedar stands, but it was not a significant driver in pine or prairie plots, supporting our prediction. The tissue chemistry data supports a different capacity to retain and recirculate $\mathrm{Ca}$ under cedar versus pine. The litter layer under cedar litter contained twice the $\mathrm{Ca}$ on an area basis than pine. This provides $\mathrm{Ca}$ that can be involved in $\mathrm{C}$ stabilization as that litter is decomposed. The differences in the different tree litters were also seen in the associated litter microbiota. Cedar may be influencing SOC retention in the surface soil layers by taking up Ca from lower horizons and concentrating it in litter. Morris et al. (2007) also found differences in SOC associated with Ca to be tree species specific. Numerous studies have noted decreases in $\mathrm{C}$ mineralization following addition of $\mathrm{Ca}$ (Lineres, 1977; Muneer and Oades, 1989a, 1989b; Baldock and Skjemstad, 2000). Brewer (2004) found that additions of $\mathrm{Ca}$ and $\mathrm{N}$ increased soil $\mathrm{C}$ on a sandy soil in a pine forest suggesting the mechanism to be stabilization of SOC by Ca. In the present study, the upper layers of the cedar soils are receiving the $\mathrm{Ca}$ from the lower layers via translocation by the cedar and needle drop. This is consistent with Pierce and Reich (2010) who showed that cedar invasion resulted in higher Ca content compared with the adjacent native prairie plots. 
The differences in the predictive models developed with structural analysis with regards to $\mathrm{C}$ and $\mathrm{N}$ dynamics support fundamental differences in processing and retention in the pine and cedar systems. The capacity to model both $\mathrm{C}$ and $\mathrm{N}$ contents were strongest under the cedar, and the capacity to model $\mathrm{N}$ under pine was strong; however, the models for $\mathrm{C}$ were poor. Models for $\mathrm{N}$ under pine appeared most strongly related to cations and $\mathrm{P}$. In terms of net change, planting pine on these sandy soils resulted in a net loss of $\mathrm{N}$ overall. The National Atmospheric Deposition Program site (http://nadp.sws.uiuc.edu/) shows an average inorganic $\mathrm{N}$ deposition of $2.7 \mathrm{~kg} \mathrm{ha}^{-1} \mathrm{yr}^{-1}$. Assuming a doubling of that to account for wet plus dry deposition (Lovett and Lindberg, 1993) and/or $\mathrm{N}$ fixation on the site suggests that $\mathrm{N}$ inputs are reasonable for biomass growth on the site. On the basis of these inputs the loss of $\mathrm{N}$ on the pine site is actually greater than the $10 \mathrm{~kg} \mathrm{ha}^{-1} \mathrm{yr}^{-1}$ calculated based on soils and wood. Berthrong et al. (2009) also found loss of $\mathrm{N}$ following afforestation was common especially following afforestation with pine.

Root-mycorrhizal relationships cannot be discounted as mechanisms for explaining differences in $\mathrm{C}$ processing on cedar vs. pine sites. The mycorrhizal symbionts differ between cedar and pine with cedar hosting arbuscular mycorrhizal fungi (Liang et al., 2008) and pine hosting ectomycorrhizal fungi (Allen, 1991). Differences in FAME profiles suggest a difference in the microbial communities under pine, cedar, and prairie especially in regards to the proportion of arbuscular mycorrhizal fungi ( $\mathrm{Ta}$ ble 8). Chapela et al. (2001) reported that ectomycorrhizal species introduced with pines following afforestation of grasslands were related to losses of soil C. Their data showed ${ }^{13} \mathrm{C}$ isotope values of the ectomycorrhizal fungi were more similar to the grassland $\mathrm{C}$ than the pine $\mathrm{C}$ suggesting that the fungi may have had preferential access to the older $\mathrm{C}$. This is consistent with the $\mathrm{C}$ losses under pine in our study.

In addition to the mycorrhizal communities, other aspects of the soil microbial community also differed under the cedars versus the pines. The cedar litter contained more microbes than the pine. This likely reflects the greater availability of substrate $\mathrm{C}$ in the cedar. The PCA was able to explain nearly $60 \%$ of the variation in FAME profiles among vegetation types, and correlation analysis showed that the FAME profiles could also be associated with differences in soil chemical properties, including $\mathrm{Ca}$, $\mathrm{Mg}$, and $\mathrm{pH}$. The fact that $\mathrm{Ca}$ seems to have a large effect on the separation of microbial communities by vegetation types correlates well with the general differences in decomposition that may be leading to differences in $\mathrm{C}$ storage in these soils. However, the additional variability in the FAME profiles (40\%) remains unexplained and is likely due to variables not measured in this study.

The role that soils ultimately play in mitigation of elevated $\mathrm{CO}_{2}$ is dependent on the size and residence time of $\mathrm{C}$ in these pools, which is controlled by species and soil textural class interactions (Paul et al., 2003; Morris et al., 2010). While researchers often quantify above- and belowground $\mathrm{C}$ pools, more emphasis must be put on the stability of C sinks (Paul et al., 2011). Vegetation through its impacts on litter and tissue quality and placement, and impact on microbial community through exudation impacts decomposition and SOC stabilization. Long-term effects of these differences as a consequence of vegetation must be evaluated and included in models created to predict future $\mathrm{C}$ sink capacity of ecosystems (Smith et al., 2012).

\section{ACKNOWLEDGMENTS}

This research was supported by the Office of Science (BER), U.S. Department of Energy grant: Ecosystem Controls on Carbon and Nitrogen Sequestration Following Afforestation of Agricultural Soils (DE-FG03-01ER63183 and DE-FG02-04ER63890) awarded to Colorado State University with subcontracts to Bradley University. We thank Dr. Kelly McConnaughay for guidance on the project and scientific and editorial comments, and Elizabeth Brewer for guidance in the lab and field. We also thank the Nebraska National forest for site access and background information.

\section{REFERENCES}

Allen, M.F. 1991. The ecology of Mycorrhizae. Cambridge Univ. Press, Cambridge, UK.

Arbuckle, J.L., and W. Wothke. 1999. Amos 4.0 users guide. SmallWaters Corp., Chicago, IL.

Bååth, E. 2003. The use of neutral lipid fatty acids to indicate the physiological conditions of soil fungi. Microb. Ecol. 45:373-383. doi:10.1007/s00248003-2002-y

Baldock, J.A., and J.O. Skjemstad. 2000. Role of the soil matrix and minerals in protecting natural organic materials against biological attack. Org. Geochem. 31:697-710. doi:10.1016/S0146-6380(00)00049-8

Berthrong, S.T., E.G. Jobbágy, and R.B. Jackson. 2009. A global meta-analysis of soil exchangeable cations, $\mathrm{pH}$, carbon, and nitrogen with afforestation. Ecol. Appl. 19:2228-2241. doi:10.1890/08-1730.1

Birdsey, R.A. 1992. Carbon storage and accumulation in United States forest ecosystems. GTR WO-59. Northeastern For. Exp. Stn., Radnor, PA.

Birgé, H.E. 2013. What happens during soil incubations? Explaining the microbial biomass, carbon availability, and temperature constraints on soil respiration. Master's thesis. Colorado State Univ., Fort Collins.

Bossio, D.A., and K.A. Scow. 1998. Impacts of carbon and flooding on soil microbial communities: Phospholipid fatty acid profiles and substrate utilization patterns. Microb. Ecol. 35:265-278. doi:10.1007/s002489900082

Boutton, T.W. 1996. Stable isotope ratios of soil organic matter and their use as indicators of vegetation and climate change. In: T. Boutton and Y. Yamaski, editors, Mass spectrometry of soils. Marcel Dekker, New York. p. 47-82.

Brewer, E.A. 2004. Impacts of calcium and nitrogen on carbon stabilization in soils of an afforested red pine stand. MS thesis. Bradley Univ., Peoria, IL.

Brown, J.R., editor. 1998. Recommended chemical soil test procedures for the North Central Region. North Central Regional Research Publication No. 221. Mo. Agric. Exp. Stn., Columbia, MO.

Burke, I.C., et al.. 2008. Soil organic matter and nutrient dynamics of shortgrass steppe ecosystems. In: W.K. Lauenroth and I.C. Burke, editors, Ecology of the Shortgrass Steppe. Oxford Univ. Press, New York. p. 306-341.

Chapela, I.H., L.J. Osher, T.R. Horton, and M.R. Henn. 2001. Ectomycorrhizal fungi introduced with exotic pine plantations induce soil carbon depletion. Soil Biol. Biochem. 33:1733-1740. doi:10.1016/S0038-0717(01)00098-0

Ellert, B.H., and E.G. Gregorich. 1996. Storage of carbon, nitrogen and phosphorus in cultivated and adjacent forested soils of Ontario. Soil Sci. 161:587-603. doi:10.1097/00010694-199609000-00004

Eusterhues, K., C. Rumpel, M. Kleber, and I. Kögel-Knabner. 2003. Stabilization of soil organic matter by interactions with minerals as revealed by mineral dissolution and oxidative degradation. Org. Geochem. 34:1591-1600. doi:10.1016/j.orggeochem.2003.08.007

Eusterhues, K., C. Rumpel, and I. Kögel-Knabner. 2005. Organo-mineral associations in sandy forest soils: Importance of specific surface areas, iron oxides and micropores. Eur. J. Soil Sci. 56:753-763.

Eusterhues, K., C. Rumpel, and I. Kögel-Knabner. 2007. Composition and radiocarbon age of HF-resistant soil organic matter in a Podzol and a Cambisol. Org. Geochem. 38:1356-1372. doi:10.1016/j.orggeochem.2007.04.001

Feller, C., and M. Bernoux. 2008. Historical advances in the study of global ter- 
restrial soil organic carbon sequestration. Waste Manage. 28:734-740. doi:10.1016/j.wasman.2007.09.022

Follett, R.F., E.A. Paul, S.W. Leavitt, A.D. Halvorson, D. Lyon, and G.A. Peterson. 1997. Carbon isotope ratios of Great Plains soils and in wheat-fallow system. Soil Sci. Soc. Am. J. 61:1068-1077. doi:10.2136/sssaj1997.03615995006100040012x

Grigera, M.S., R.A. Drijber, R.A. Shores-Morrow, and B.J. Wienhold. 2007. Distribution of the arbuscular mycorrhizal biomarker C15:1cis11 among neutral, glycol and phospholipids extracted from soil during reproductive growth of corn. Soil Biol. Biochem. 39:1589-1596. doi:10.1016/j.soilbio.2007.01.009

Grigera, M.S., R.A. Drijber, K.M. Eskridge, and B.J. Wienhold. 2006. Soil microbial biomass relationships with organic matter fractions in a Nebraska corn field mapped using apparent electrical conductivity. Soil Sci. Soc. Am. J. 70:1480-1488. doi:10.2136/sssaj2005.0331

Guo, L.B., and R.M. Gifford. 2002. Soil carbon stocks and land use change: A meta- analysis. Glob. Change Biol. 8:345-360. doi:10.1046/j.13541013.2002.00486.x

Harris, D., and E.A. Paul. 1989. Automated analysis of ${ }^{15} \mathrm{~N}$ and ${ }^{14} \mathrm{C}$ in biological samples. Commun. Soil Sci. Plant Anal. 20:935-947. doi:10.1080/00103628909368127

Harrison, K.G., W.M. Post, and D.D. Richter. 1995. Soil carbon turnover in a recovering temperate forest. Global Biogeochem. Cycles 9:449-454. doi:10.1029/95GB02380

Hernandez-Ramirez, G., T.J. Sauer, C. Cambardella, J.R. Brandle, and D.E. James. 2011. Carbon sources and dynamics in afforested and cultivated corn belt soils. Soil Sci. Soc. Am. J. 75:216-225. doi:10.2136/sssaj2010.0114

Högberg, M.N., P. Högberg, and D.D. Myrold. 2007. Is microbial community composition in boreal forest soils determined by $\mathrm{pH}, \mathrm{C}$-to- $\mathrm{N}$ ratio, the trees, or all three? Oecologia 150:590-601. doi:10.1007/s00442-006-0562-5

Hooker, T.D., and J.E. Compton. 2003. Forest ecosystem carbon and nitrogen accumulation during the first century after agricultural abandonment. Ecol. Appl. 13:299-313. doi:10.1890/1051-0761(2003)013[0299:FEC ANA] 2.0.CO;2

Houghton, R.A., J.L. Hackler, and K.T. Lawrence. 1999. The U.S. carbon budget: Contributions from land use change. Science 285:574-578. doi:10.1126/ science.285.5427.574

Jackson, R.B., J.L. Banner, E.G. Jobbágy, W.T. Pockman, and D.H. Wall. 2002. Ecosystem carbon loss with woody plant invasion of grasslands. Nature 418:623-626. doi:10.1038/nature00910

Jackson, R.B., et al. 2000. Belowground consequences of vegetation change and their treatment in models. Ecol. Appl. 10:470-483. doi:10.1890/10510761(2000)010[0470:BCOVCA $] 2.0 . \mathrm{CO} ; 2$

Johnson, D.W. 1992. Effects of forest management on soil carbon storage. Water Air Soil Pollut. 64:83-120. doi:10.1007/BF00477097

Kaiser, K., K. Eusterhues, C. Rumpel, G. Gaggenberger, and I. Kögel-Knabner. 2002. Stabilization of organic matter by soil minerals-Investigations of density and particle-size fractions from two acid forest soils. J. Plant Nutr. Soil Sci. 165:451-459. doi:10.1002/1522-2624(200208)165:4<451::AIDJPLN451>3.0.CO;2-B

Kay, B.D., and D.A. Angers. 2000. Soil structure. In: M.E. Sumner et al., editors, Handbook of soil science. CRC Press, Boca Raton, FL. p. A229-A276.

Kaye, J.P., S.C. Hart, P.Z. Fulé, W.W. Covington, M.M. Moore, and M.W. Kaye. 2005. Initial carbon, nitrogen, and phosphorus fluxes following ponderosa pine restoration treatments. Ecol. Appl. 15:1581-1593. doi:10.1890/04-0868

Kögel-Knabner, I., G. Guggenberger, M. Kleber, E. Kandeler, K. Kalbitz, S. Scheu, K. Eusterhues, and P. Leinweber. 2008. Organo-mineral associations in temperate soils: Integrating biology, mineralogy, and organic matter chemistry. J. Plant Nutr. Soil Sci. 171:61-82. doi:10.1002/jpln.200700048

Liang, Z., R.A. Drijber, D.J. Lee, I.M. Dwiekat, S.D. Harris, and D.A. Wedin. 2008. A DGGE-cloning method to characterize arbuscular mycorrhizal community structure in soil. Soil Biol. Biochem. 40:956-966. doi:10.1016/j.soilbio.2007.11.016

Lineres, M. 1977. Contribution de l'ion calcium à la stabilisation biologique de la matière organique des sols. Thèse Doc. Spéc., Univ. de Bordeaux III, Bordeaux, France.

Lovett, G.M., and S.E. Lindberg. 1993. Atmospheric deposition and canopy interactions of nitrogen in forests. Can. J. For. Res. 23:1603-1616. doi: $10.1139 / \mathrm{x} 93-200$

Masiello, C.A., O.A. Chadwick, J. Southon, M.S. Torn, and J.W. Harden. 2004. Weathering controls on mechanisms of carbon storage in grassland soils. Global Biogeochem. Cycles 18:GB4023. doi:10.1029/2004GB002219
Means, J.E., H.A. Hansen, G.J. Koerper, P.B. Alaback, and M.W. Klopsch. 1994. Software for computing plant biomass-BIOPAK Users Guide. PNWGTR-340. Pac. Northwest Res. Stn., Portland, OR.

Morris, S.J., S. Bohm, S. Haile-Mariam, and E.A. Paul. 2007. Evaluation of carbon accrual in afforested agricultural soils. Glob. Change Biol. 13:11451156. doi:10.1111/j.1365-2486.2007.01359.x

Morris, S.J., R. Conant, N. Mellor, E.A. Brewer, and E.A. Paul. 2010. Controls on soil carbon sequestration and dynamics: Lessons from land-use change. J. Nematol. 42:78-83.

Muneer, M., and J.M. Oades. 1989a. The role of Ca-organic interactions in soil aggregate stability 1: Laboratory studies with glucose ${ }^{14} \mathrm{C}, \mathrm{CaCO}_{3}$ and $\mathrm{CaSO}_{4} \cdot 2 . \mathrm{H}_{2} \mathrm{O}$. Aust. J. Soil Res. 27:401-409. doi:10.1071/SR9890401

Muneer, M., and J.M. Oades. 1989b. The role of Ca-organic interactions in soil aggregate stability 2: Field studies with ${ }^{14} \mathrm{C}$-labelled straw, $\mathrm{CaCO}_{3}$, $\mathrm{CaSO}_{4} \cdot \mathrm{H}_{2}$ O. Aust. J. Soil Res. 27:389-399. doi:10.1071/SR9890389

Norris, M.D., J.M. Blair, and L.C. Johnson. 2001a. Land cover change in eastern Kansas: Litter dynamics of closed canopy eastern red cedar forests in tallgrass prairie. Can. J. Bot. 79:214-222.

Norris, M.D., J.M. Blair, L.C. Johnson, and R.B. McKane. 2001b. Assessing changes in biomass, productivity, and $\mathrm{C}$ and $\mathrm{N}$ stores following Juniperus virginiana forest expansion into tallgrass prairie. Can. J. For. Res. 31:1940-1946.

Oades, J.M. 1988. The retention of organic matter in soils. Biogeochemistry 5:35-70. doi:10.1007/BF02180317

O'Leary, M.H. 1981. Carbon isotope fractionation in plants. Phytochemistry 20:553-567. doi:10.1016/0031-9422(81)85134-5

Olsson, P.A. 1999. Signature fatty acids provide tools for determination of the distribution and interactions of mycorrhizal fungi in the soil. FEMS Microbiol. Ecol. 29:303-310. doi:10.1111/j.1574-6941.1999.tb00621.x

Olsson, P.A., E. Bååth, I. Jacobsen, and B. Söderström. 1995. The use of phospholipid and neutral lipid fatty acids to estimate biomass of arbuscular mycorrhizal fungi in soil. Mycol. Res. 99:623-629. doi:10.1016/S09537562(09)80723-5

Pacala, S.W., et al. 2001. Consistent land- and atmosphere-based U.S. carbon sink estimates. Science 292:2316-2320. doi:10.1126/science. 1057320

Parton, W.J., et al. 1993. Observations and modeling of biomass and soil organic matter dynamics for the grassland biome worldwide. Global Biogeochem. Cycles 7:785-809. doi:10.1029/93GB02042

Paul, E.A., and F.E. Clark. 1996. Soil microbiology and biochemistry. 2nd ed. Academic Press, San Diego, CA.

Paul, E.A., R.F. Follett, M. Haddix, and E. Pruessner. 2011. Soil N dynamics related to soil $\mathrm{C}$ and microbial changes during long-term incubation. Soil Sci. 176:527-536. doi:10.1097/SS.0b013e31822ce6e8

Paul, E.A., S.J. Morris, and S. Böhm. 2001. The determination of soil C pool size and turnover rates: Biophysical fractionation and tracers. In: R. Lal, J.M. Kimble, R.F. Follett, and B.A. Stewart, editors, Assessment methods for soil C pools. CRC Press, Boca Raton, FL. p. 193-206.

Paul, E.A., S.J. Morris, R.T. Conant, and A.F. Plante. 2006. Does the acid hydrolysis-incubation method measure meaningful soil carbon pools? Soil Sci. Soc. Am. J. 70:1023-1035. doi:10.2136/sssaj2005.0103

Paul, E.A., S.J. Morris, J. Six, K. Paustian, and E.G. Gregorich. 2003. Interpretation of soil carbon and nitrogen dynamics in agriculture and afforested soils. Soil Sci. Soc. Am. J. 67:1620-1628. doi:10.2136/sssaj2003.1620

Pierce, A.M., and P.B. Reich. 2010. The effects of eastern red cedar (Juniperus virginiana) invasion and removal on dry, bluff prairie ecosystems. Biol. Invasions 12:241-252. doi:10.1007/s10530-009-9446-z

Poeplau, C., A. Don, L. Vesterdal, J. Leifeld, B. van Wesemael, J. Schumacher, and A. Gensior. 2011. Temporal dynamics of soil organic carbon after land-use change in the temperate zone- carbon response functions as a model approach. Glob. Change Biol. 17:2415-2427. doi:10.1111/j.13652486.2011.02408.x

Pool, R.J. 1953. Fifty years on the Nebraska National Forest. Nebr. Hist. 34:139-179.

Post, W.M., and K.C. Kwon. 2000. Soil carbon sequestration and landuse change: Processes and potential. Glob. Change Biol. 6:317-327. doi:10.1046/j.1365-2486.2000.00308.x

Pregitzer, K.S., and B.J. Palik. 1997. Changes in ecosystem carbon 46 years after establishing red pine (Pinus resinoa) on abandoned agricultural land in the Great Lakes region. In: E.A. Paul et al., editors, Soil organic matter in temperate agroecosystems: Long-term experiments in North America. CRC Press, Boca Raton, FL. p. 263-272.

SAS. 1995. Statistical Analysis System user's guide: Statistics. Version 6.2. SAS 
Inst., Cary, NC.

Schmidt, M.W.I., et al. 2011. Persistence of soil organic matter as an ecosystem property. Nature 478:49-56. doi:10.1038/nature 10386

Schnell, R.L. 1976. Biomass estimates of eastern red cedar tree components. Technology Note B15. Tenn. Val. Auth., Norris, TN.

Six, J., P. Callewaert, S. Lenders, S. DeGryze, S.J. Morris, E.G. Gregorich, E.A. Paul, and K. Paustian. 2002. Measuring and understanding carbon storage in afforested soils by physical fractionation. Soil Sci. Soc. Am. J. 66:19811987. doi:10.2136/sssaj2002.1981

Smith, D.L., and L.C. Johnson. 2003. Expansion of Juniperus viginiana L. in the Great Plains: Changes in soil organic carbon dynamics. Global Biogeochem. Cycles 17:1062. doi:10.1029/2002GB001990

Smith, P., et al. 2012. Towards an integrated global framework to assess the impacts of land use and management change on soil carbon: Current capability and future vision. Glob. Change Biol. 18:2089-2101. doi:10.1111/ j.1365-2486.2012.02689.x
Vestal, J.R., and D.C. White. 1989. Lipid analysis in microbial ecology: Quantitative approaches to the study of microbial communities. Bioscience 39:535-541. doi:10.2307/1310976

Werth, M., and Y. Kuzyakov. 2010. ${ }^{13} \mathrm{C}$ fractionation at the root-microorganism-soil interface: A review and outlook for partitioning studies. Soil Biol. Biochem. 42:1372-1384. doi:10.1016/j.soilbio.2010.04.009

Wynn, J.G., and M. Bird. 2007. $\mathrm{C}_{4}$-derived soil organic matter decomposes faster than its $\mathrm{C}_{3}$ counterpart in mixed $\mathrm{C}_{3} / \mathrm{C}_{4}$ soils. Glob. Change Biol. 13:2206-2207. doi:10.1111/j.1365-2486.2007.01435.x

Zak, D.R., D.B. Ringelberg, K.S. Pregitzer, D.L. Randlett, D.W. White, and P.S. Curtis. 1996. Soil microbial communities beneath Populus grandidentata grown under elevated atmospheric $\mathrm{CO}_{2}$. Ecol. Appl. 6:257-262. doi: $10.2307 / 2269568$

Zinn, Y.L., R. Lal, J.M. Bigham, and D.V.S. Resck. 2007. Edaphic controls on soil organic carbon retention in the Brazilian Cerrado: Texture and mineralogy. Soil Sci. Soc. Am. J. 71:1204-1214. doi:10.2136/sssaj2006.0014 